\title{
Ethics as commodity in higher education of South African natural science and engineering students
}

\begin{abstract}
Author:
Jean du Toit ${ }^{1}$

Affiliation:

${ }^{1}$ School of Philosophy,

North-West University,

South Africa

Correspondence to:

Jean du Toit

Email:

jean.dutoit@nwu.ac.za

Postal address:

PO Box 208, Building F13,

School of Philosophy

and Ethics, North-West

University, Potchefstroom

2520 South Africa
\end{abstract}

Dates:

Received: 20 July 2011

Accepted: 03 Nov. 2011

Published: 14 Nov. 2012

How to cite this article:

Du Toit, J., 2012, 'Ethics as commodity in the higher education of South African students in natural science and engineering', Koers

- Bulletin for Christian

Scholarship 77(1), Art.

\#30, 8 pages. http://dx.doi.

org/10.4102/koers.v77i1.30

Note:

This article was developed from a paper delivered at the Koers-75 Conference on 'Worldview and Education', held in Potchefstroom, South Africa, from 30 May to 02 June 2011

Hierdie artikel is ' $n$ verdere ontwikkeling van 'n voordrag gelewer by die Koers-75 Konferensie oor 'Worldview and Education' in Potchefstroom, Suid-Afrika, vanaf 30 Mei tot 02 Junie 2011.

(C) 2012. The Authors. Licensee: AOSIS OpenJournals. This work is licensed under the Creative Commons Attribution License.
The fields of the natural sciences are increasingly shying away from purely theoretical approaches to knowledge and are instead looking toward real-world applications and products to be derived from research projects. This phenomenon is seen even in the academic setting, which increasingly seems to mimic the goals of the outcome-driven engineering world. Such developments are deemed necessary in a worldwide economy that is driven more by practical economic results and less by the ideal of contributing to discipline-specific facts and knowledge. This shift in research-perspective means that science and engineering are faced with a host of ethical and social issues which extend beyond the confines of the laboratory. With these changes, the importance of an ethical grounding for graduate students becomes ever more pressing. This article will look at the influence that a purely positivist worldview may have on the ethical and value-related education of university students in the natural sciences and engineering. It will attempt to show how the teaching of ethical approaches need not be seen as an obstacle for the training of a potential scientist or engineer, but rather as an opportunity for growth in the individual as a contributing member of his or her society and immediate community. A solution to this continually growing need for ethical grounding is suggested: educators should look at the underlying worldviews and collateral or hidden curriculum (that which is not taught formally in classes, but which the students learn anyway) and the null curriculum (that which is not taught in classes) to provide their students with ethical guidance, rather than simply focusing on adding extra ethics modules to highly technical university or college courses.

Etiek as kommoditeit in die opleiding van hoër onderwys-studente in die natuurwetenskappe en ingenieurswese in Suid-Afrika. Die velde van die natuurwetenskappe beweeg al verder weg van suiwer teoretiese benaderings tot kennis en word toenemend ' $n$ soeke na toepassings en produkte as die resultaat van navorsingsprojekte. Hierdie verskynsel word selfs in die akademiese milieu aangetref, waar die natuurwetenskap toenemend die doelwitte van die uitkoms-gebaseerde ingenieurswêreld nastreef. Sodanige ontwikkelings word as noodsaaklik beskou in ' $n$ wêreldwye ekonomie wat al hoe meer deur praktiese ekonomiese resultate gedryf word en al hoe minder deur die ideaal om by te dra tot navorsingsveld-spesifieke feite en kennis. Hierdie verskuiwing in navorsingsfokus beteken dat natuurwetenskappe en ingenieurswese met 'n reeks sosiale en etiese probleme gekonfronteer word wat wyer strek as die grense van die laboratorium. Met hierdie veranderinge in gedagte word die etiese begronding van graduandi belangriker. Hierdie artikel sal poog om na die invloed wat ' $n$ suiwer positiwistiese wêreldbeskouing op die etiese en waarde-geassosieerde opleiding van universiteitstudente van die natuurwetenskappe en ingenieurswese het, te kyk. Daar sal gepoog word om aan te toon dat opleiding in die veld van etiese benaderings nie as ' $n$ struikelblok gesien moet word nie, maar eerder as ' $n$ geleentheid vir groei van die individu as deel van die samelewing en as ' $n$ lid wat 'n bydrae tot sy of haar gemeenskap lewer. 'n Oplossing vir die tekort aan etiese opleiding word ook voorgestel: Eerder as om slegs addisionele etiek-modules tot hoogs-tegniese kollege en universiteitskursusse toe te voeg, behoort na die onderliggende wêreldbeskouing en die versteekte en nul-kurrikula van grade gekyk te word om studente eties te begelei.

\section{A bird's eye view of global and South African contexts and motivations}

This article was presented in a simplified form at the International Koers Conference in May/ June 2011 in Potchefstroom, South Africa, on the occasion of the 75th anniversary of the Koers: Bulletin for Christian scholarship. The theme was 'Worldview and Education', two facets which are intrinsically linked to each other. The original presentation approached the subject of the teaching of ethics to higher education students in natural science and engineering in a much more exploratory manner, without really providing suggestions for improving the current situation. I hope that this shortcoming will be addressed in this article. 
No discussion of worldviews is complete without mentioning the dominant worldviews that play a role in today's society, such as the Modern Western worldview which South Africa appears to be 'borrowing' from North America and Europe. The Modern Western worldview is characterised by a secular, materialistic approach to technological and scientific development (Van der Walt 2003:110-115). It is therefore no surprise that the financial crisis from 2007 to 2010 has had a major influence on science funding, resulting in many budget cuts in science research in the USA (Kobilnyk 2008; Semeniuk, Tollefson \& Wadman 2011). However, in many developing nations the trend seen in the USA appears to be reversed; third-world countries are spending more money on research and development. A surge in funding for science and technology has been observed in India, which is set to double its spending on science and research to compete with nations such as Brazil and China (Mishra 2011). The same trend has been noted in South Africa, where it was announced on 24 May 2011 that R4.4 billion would be allocated to boost scientific research and development in South Africa. Former Minister of Education, Naledi Pandor, stated that South Africa needed to devote more resources to science and technology if the country wished to achieve its ambitions of building a knowledge-based economy (Prinsloo 2011). This forward-thinking attitude is also reflected in the financial reports of the South African National Research Foundation (NRF), which spent R763 446000 on grants and bursaries for the year ending 31 March 2010 (National Research Foundation 2010). This is a considerable increase from the R503 785000 spent in 2008 (National Research Foundation 2009).

The motivation behind this increase in spending is clear: scientific and technological development is expected to lead to the economic development of third world countries. John Mugabe, the Science and Technology Adviser to the New Partnership for Africa's Development (NEPAD), said that the increase in funds allocated for these technical fields in South Africa demonstrated that 'science, technology and innovation matter, and will continue to be sources of economic change and growth' (Scott 2007). Julie Cleverdon, acting head of the MTN ScienCentre in Cape Town, said that the additional funding would 'encourage bright young South Africans to use their talents in the scientific field and find solutions to many of the problems that plague us' (Scott 2007). A budgetary increase for scientific research is expected to lead inevitably to economic growth. This presents an almost ideological idea of technological progress paving the way towards a brighter future for South Africa's society, an ideological idea similar to that which Bob Goudzwaard identified in his book Idols of our Time (Goudzwaard 1984:9-13). Furthermore, this economic growth is expected to lead to practical solutions for a myriad of social problems (Scott 2007). Whilst history clearly shows that technological development leads to the betterment of society in certain respects, the prospects are not always clear-cut (Monsma 1986:200-222). Technology and development have brought a series of serious problems with them, such as the threat of environmental disaster and the danger posed by misuse of nuclear potential; some sources even claim that reckless development is bringing humanity closer to ruin (Florman 1994:ix; Monsma 1986:31-36, Schuurman 1995:3-4). With these problems in mind, and the recognition that technology should not simply be seen as a secular saviour of humanity (Goudzwaard 1984:9-29), it should be recognised that carelessly 'throwing more money' into research and development might not be the best way to deal with South Africa's range of social dilemmas.

These considerations should also not be overestimated or overshadow the beneficial aspects of science and technological development. Both science and engineering have elevated society to greatness (Florman 1994:ix-xi; Mitcham 1994:161-192), with responsible science and engineering continuing to hold immense promise ${ }^{1}$. The general consensus in South Africa appears to be that scientific research should not simply be of theoretical value, but should also be practically applicable to the society in which the research is done. Science is expected to function in the same way as engineering - albeit in a different area of expertise - with the service-motif remaining central and with the eventual goal of economic gains. Pure knowledge-gathering is considered superfluous, unless such knowledge can be defined in terms of eventual economic benefits. Scientists are expected, even required, to be more innovative than ever before. This innovation does not refer to simple inventions; it deals with the social applications of research (Nussbaum 2009). In other words, practical social applications determine which research is financed in science, rather than the more classic view of 'increasing human knowledge'. ${ }^{2}$ Art may be done for Art's sake, divorced from any moral or utilitarian function, but scientific projects can no longer be done for Science's sake alone.

In short, science must now do what engineering does: To direct 'The great sources of power in nature for the use and the convenience of humans' (McGraw-Hill Encyclopedia of Science and Technology 2008). This entails a shift of once 'academic' disciplines to the public sphere and towards a service-driven ideal, presenting students of the natural sciences with multiple new challenges that were once only faced by engineering students. This does not necessarily mean that engineering students are better prepared for these new challenges (in terms of ethics training during their higher education) than natural science students. However, they should also be prepared for both the workplace that they will enter and the social issues which are associated with it. Teachers should continually ask what provisions, if any, are made in the higher education system of South Africa for future scientists and engineers to tackle both the existing and emerging problems that are found in the rapidly changing scientific and engineering worlds (and if these provisions, in their current form, are sufficient to address the social and ethical problems that these students are bound to 1.Note the descriptive term responsible when referring to science and engineering.

2.'Increasing human knowledge' does not necessarily describe the history of science adequately (as discussed by Thomas Kuhn 1962). However, I am here referring to the traditionally held public view of the goals of science. 
face). In essence, educators should realise that the scientist and engineer are no longer faced only with simple technical problems, but rather with a host of social and ethical ${ }^{3}$ dilemmas as the direct result of new scientific developments and the increasing prominence that economic factors take in their respective industries. The ethical challenges these students will face cannot be disregarded.

\section{An explanation of scope of the article}

Broadly speaking, scientists investigate the natural world to systematically elucidate general principles from the behaviour and structure of the physical and natural world (by means of observation and experimentation) (Fleck 1979:20-23; Wilson 1999), whilst engineers use established principles (derived from primary scientific research) to solve societal problems and to create new inventions (Shapin 2008; U.S. Department of Labour 2010-2011). This last definition seems a bit too broad, however, and may apply to a number of different entities. A more comprehensive definition has been offered by the American Engineers' Council for Professional Development (ECPD), which stated in 1947 that engineering is:

the creative application of scientific principles to design or develop structures, machines, apparatus, or manufacturing processes, or works utilizing them singly or in combination; or to construct or operate the same with full cognizance of their design; or to forecast their behavior under specific operating conditions; all as respects an intended function, economics of operation and safety to life and property. (Engineers' Council for Professional Development 1947)

It is necessary to establish these definitions early on, as both natural science and engineering education will be discussed in this article. One might argue that these are disparate fields, and from general definitions this may indeed be inferred. On a more fundamental level, however, it may be said that the approaches to the training of natural science and engineering students are strikingly similar. Both are highly technical fields that require their students to be exposed to a certain way of solving problems. Egbert Schuurman identifies this as the technological-scientific method (Schuurman 2009:29-35). The approach utilised in natural science and engineering is often positivist in nature (as befits those fields of study), but this positivist approach is not necessarily applicable to the entirety of human existence (areas beyond the mere technical, such as the social world). It is my belief that both of these fields may benefit greatly if the value of the integration of a fundamentally ethical mindset into the courses associated with these disciplines is recognised and if this ethical approach is made applicable to the social world wherein the scientist or engineer will function. The links between engineering and the social world are quite apparent. It may, for example, be noted that the idea of safety is important when defining the goals of engineering; responsible service to the community is a central part of good engineering and implies an ethical imperative (ECPD 1947). This ethical imperative (responsible

3.Ethics is defined as a branch of moral philosophy that deals with questions of morality (Rollin 2006:31-65). In this article, ethics is generally considered in relation to society: how can a scientist or engineer determine what is right during the course to society: how can a scientist or engineer determine what is right during the course
of his or her work with relation to the community he or she must serve? In the most of his or her work with relation to the community he
basic and broad sense, what is right and wrong? social application) is very closely linked to the engineering field because of its close ties with the social world. However, as stated in the first section of this article, the natural sciences are unavoidably moving nearer to the social world as its research is continually driven to become more practical in the everyday spheres of communities.

One might argue that there are many prescriptions for engineers on how to act ethically, that is, the National Society for Professional Engineers' (NSPE) Code of Ethics for Engineers or the requirements of the Engineering Council of South Africa (ECSA), which plays a major role in the South African context. The same guidelines exist for natural scientists, that is, the Code of Ethics of the American Society for Biochemistry and Molecular Biology of the American Society for Biochemistry and Molecular Biology (ASBMB) or outlines on bioethics by the Ethics Institute of South Africa (EISA). However, as Haws (2004) states, these 'prescriptions' present students with simple formulated dogma. He argues for the importance of a meta-ethical approach, giving students the ability to deal with unique situations. I support his position; a meta-ethical perspective is the most viable approach to allow students to deal with the unique problems they will face in the workplace and in these fast-developing fields. More details for this reasoning will be given later on in this article, where new developments in the scientific field are discussed. Briefly, it is expected that new research and technological developments will be so different from that which students face today that only a meta-ethical approach of heuristic problem-solving will allow the student to deal adequately with the social and ethical situations they may find themselves in during the course of their careers.

But perhaps a first step in realising such a meta-ethical approach in a South African context is for higher education educators to recognise that ethical issues are indeed important, on a very fundamental level, for student development, rather than approaching the subject as an obstacle that should be dealt with in perhaps a few ethics courses that are tangentially linked to some technical degrees and certificates in South Africa.

It is conceded that the natural scientist or engineer is not an ethicist, and it is not advocated that ethical teaching take the place of the technical training of science and engineering students. Ethical theorists will always be needed for particularly difficult, varied, precise or esoteric ethical problems and dilemmas, but the ability of an engineer or scientist to act ethically in their jobs seems to be an essential skill that could add value to both the professional and personal lives of these students (Rollin 2006:11-30). An argument should therefore be made for the value of ethics in the face of the disregard it is sometimes shown in the traditional teaching approaches utilised in these technical fields, as ethics may be beneficial for both the students themselves and their communities.

A concern of many educators in these disciplines may be that the integration of ethics into the courses will bog down 
the technical training of students with unnecessary extra modules. This point is justified, which provides the context for my suggestion later in the article regarding the role of educators. For now I will simply state that adding an ethics module or two to a course may engage with the matter at hand (indeed, ethics as an additional module in any technical degree or certificate is an essential component of effective student growth), but these additional ethics modules alone will not lead to the full development of the scientist or engineer to face the challenges of the modern world (and also of the modern marketplace).

\section{Some examples from different institutions}

Different institutions have responded in various ways to the idea that ethics should form an integral part of the higher education environment for engineers and natural scientists. Some have embraced the challenge of preparing their students for a new marketplace, whilst others have done little to advance ethics education. In the following section I will look at a few of the more positive responses to the challenge from national and international institutions. These examples are not meant to provide a complete listing of all institutions (that would require several articles!); instead it is intended to give flavour to some of the comments already made.

The Pennsylvania State University instituted a first-year seminar entitled 'How Good Engineers Solve Tough Problems', which included five engineering ethics cases (Lau 2004). An inherent goal of the course is to focus on maximalist ethics, to lead engineers to do the maximum amount of good and least amount of harm within the confines of their projects, rather than a minimalist approach, which focuses on 'what not to do' (prescriptive). This distinction is the basic difference between a set list of rules which should be followed and obeyed (minimalist ethics), and giving the individual student the ability to deal rationally with an ethical dilemma in the workplace. The former, which is notably easier to do, may be found lacking when unexpected situations arise. Furthermore, minimalist ethics cannot lead to the full development of a morally contributing, ethical natural scientist or engineer as the guidelines given may remain only words on a paper for many students. Students responded positively to the PSU course, and noted its value not only for their future professional careers, but also for their everyday lives.

Gil-Martín, Hernandez-Montes and Segura-Naya (2010) noted that in a professional ethics course for civil engineers at the University of Granada, the students were not only interested in the course for their professional development, but also for its application in their everyday lives. This can be linked to the feedback on the Pennsylvania State University course and highlights the fact that ethical discourse is important for the professional and personal lives of the students.
In a South African context, several institutions have taken up the baton for ethics education with a clear view towards the concerns already mentioned. The University of Pretoria established a multidisciplinary education programme in health research ethics, the South African Research Ethics Training Initiative (SARETI) (The South African Research Ethics Training Initiative 2011), whilst the University of Cape Town formed the International Research Ethics Network for Southern Africa (IRENSA) (International Research Ethics Network for Southern Africa 2011). These types of initiatives are blazing the way forward for South African ethics education in the natural and health sciences. Furthermore, the North-West University is one of the few universities that have modules on philosophy and ethics in place for natural science and engineering students on second and third year level (North-West University 2011). Such additional modules are worthwhile contributors towards fulfilling official requirements for engineering degree accreditation by ECSA (referring to the exit level outcome 7, 'Impact of engineering activity', and exit level outcome 10, 'Engineering professionalism') (Engineering Council of South Africa 2004), whilst also enhancing the theoretical foundations of students' ethics education. I do believe, however, that a broader view on ethics education is needed, as I will discuss later in this article when I refer to the role of the educator.

\section{New developments and ethics boards}

I have already mentioned the economic and social context that natural science and engineering face in South Africa, but I have not given much attention to the need created by new developments within these fields that have a direct bearing on ethics education. New scientific developments in the natural sciences are shifting the boundaries of what is possible. Breakthroughs in the sub-discipline of biotechnology (for example, the use of stem cell technology and precision gene therapy in humans (Yusa et al. 2011)) are shifting the moral boundaries of society (Schuurman 1995:3). These developments open up new horizons of technological development and may be of great benefit to society at large, but often also have major moral and ethical implications. This suggests an increased need for the critical ethical evaluation of research and development. It appears as though scientists and engineers are at a crossroads: on the one hand there is an almost unlimited potential for useful development that could benefit society, but on the other hand there is the risk of harming society and individuals through unethical actions.

Recently, a microbicide gel that may reduce the risk of contracting HIV was developed by the Centre for the AIDS Programme of Research in South Africa (CAPRISA) and described in the paper 'Effectiveness and Safety of Tenofovir Gel, an Antiretroviral Microbicide, for the Prevention of HIV Infection in Women' (Karim et al. 2010). The study had important ethical implications that were associated with the trial. These included, but were not limited to, testing the trial gel on sexually-active, HIV-uninfected women in the rural KwaZulu-Natal area by using both the trial gel and a placebo. This is an ethically complex and morally challenging study, one with implications that reach far beyond the laboratory and is characteristic of the situation that scientists may face 
when they are dealing with the realities of the social world. The experimental trial was approved by several ethics committees, which included the University of KwaZuluNatal's Biomedical Research Ethics Committee, but little attention is given to ethics in the paper. It may not be amiss to wonder whether the authors truly considered the ethical and social implications of the study, or merely appealed to the authority of an ethics board in the research process.

Scientists and engineers often say that ethics boards or committees have the responsibility to follow up on the ethical implications of their research methodology (for example in the Tenofovir study). 'Why do I need any background in ethics?' a scientist may therefore ask. Unfortunately, these boards may be composed of other scientists or engineers who, although they are highly skilled in the technical aspects of their field, may not have much background in ethics and who may therefore only follow a simple checklist (similar to the prescriptions used by the NSPE and ECSA, as described earlier). The central problem is that no checklist can make sufficient provision for the rapidly changing scientific world described earlier. On the other hand, the board may be composed of ethicists who struggle to understand the technical complexities of research projects. Even if technical persons as well as ethicists form a part of the ethics board, there is always the risk that important ramifications of the study may be missed because of the difficulties of communicating from different perspectives. Furthermore, adequate ethics training or background knowledge should be regarded as a necessary prerequisite for holding a position on an ethics board, although some ethics boards do not consider it essential (an observation made from personal experience). This casts serious doubts on the claim that ethics boards can function as the only moral guardians for scientific research ${ }^{4}$.

Another problem that arises is that only the scientist or engineer who is directly involved with his or her work is fully aware of the obscure details of each trial, experiment or developmental project. Often the need for ethical endorsement results in a tussle between the researcher and the ethics board, one side desperately aiming for official endorsement and the other trying to apply an official set of guidelines. The result is a frustrated researcher who may be inclined to change details of his report in order to obtain the board's approval, an uninformed ethics board and a general loss of research time. In the end, the researcher may simply carry on with his original, ethically unapproved experiments and 'change' the experimental setup report for final publication. This is a possibility that has broader implications not only for ethics, but also for academic honesty. Even worse, the researcher may skip the ethics board and go directly to an independent medical professional known personally by him or her, who may have even less training in the application of ethics to scientific research. This attitude in some researchers shows a lack of understanding of the basic motivation for ethical endorsement in the first place and hints at a potentially volatile situation for the future of ethical research and

4.There are, of course, competent boards of ethical experts and this point should not suggest that a rash generalisation should be made. Any ethical committee that
makes use of a philosopher or ethicist seems many times more competent than a makes use of a philosophe
committee that does not. development in South Africa. An adequate ethics education, however, will allow the researcher to recognise the need for ethical conduct in research, to create experimental designs which generate ethically sound results and to contribute to his or her community. An ethically structured setup will also ensure ethical endorsement in a timely manner. ${ }^{5}$

The Tenofovir research paper mentioned earlier in this section is a prime example of scientific research functioning in the social sphere of South Africa. Care should be taken to avoid an ethically volatile situation (as mentioned in the previous paragraph). The Tenofovir research is an attempt to create a product that is marketable and profitable and is indicative of the type of research that will be done by natural scientists in the future. A heuristic approach of conscious understanding of such unique moral situations must be cultivated amongst students. This kind of approach should reach beyond the scope of mere technical problem-solving and give the student tools to act ethically in an unpredictable future and in a morally challenging working environment. Appealing to the authority of ethics boards may simply not be enough for scientists and engineers facing such complex situations.

\section{A suggestion for the role of the educator}

The educator stands at the cutting edge of these challenges and changes. How may the educator deal with the situations mentioned in the previous sections? Firstly, the educator should be open to the idea of teaching ethics as part of science and engineering degrees, because doing so leads to the development of the student not only on a professional level, but also on a personal level. Furthermore, the following strategies may help cultivate a meta-ethical approach to new problems in the students' fields, which is a more useful way of allowing students to deal with ethical dilemmas later in life than focusing on minimalist ethics alone.

\section{The hidden and null curriculum}

Elliot Eisner (1994) identified three kinds of curricula: The explicit curriculum (what is taught directly, that is, theoretical aspects), the implicit curriculum (collateral, hidden) and the null curriculum (Flinders et al. 1986). These are the ways in which schools and higher education systems 'teach'. The explicit curriculum is the theoretical aspects that the student deals with as part of his or her technical course and in subjects such as biology, engineering design, programming and physics. It also includes the 'theory' of ethics as taught in any additional ethics or philosophy modules that the student must take as part of his and her degree or course. The importance of the explicit curriculum as part of academic education is rarely disputed.

However, in the case of higher education ethics, educators should teach students to function in an ethical manner even in situations which may appear to be only tangentially related to the ethical sphere. Ethics is a practical part of life, not just

5.The basic problem of inadequately structured or poorly functioning ethics boards still exists, but this falls beyond the scope of the current article and does not play a role in all institutions. 
an academic discipline (Rollin 2006:11-30). This approach to teaching reaches beyond the explicit curriculum and relates to the concepts of the hidden curriculum (also called the collateral curriculum) and the null curriculum, two concepts that seem almost esoteric in the higher education system of South Africa but which may be of use when attempting to find solutions for the challenge of incorporating ethics education into highly technical fields of study.

Generally, the hidden curriculum refers to that which is not taught formally in classes, but which students learn anyway (Flinders et al. 1986). It includes aspects such as values and expectations that are not part of the formal curriculum, but which students nevertheless do learn. The hidden curriculum includes aspects such as the division of subjects (mathematics as a different discipline, in the academic setting, from arts, for example) or degrees of achievement (the difference between passing, failing and distinction in a certain course) (Flinders et al. 1986). In terms of ethics education, the hidden curriculum may refer to the implicit ideas concerning the necessity of ethics or moral discourse that educators convey to students, or to educators' personal beliefs on what is right or wrong, unconsciously or overtly conveyed to students during their classes. The role of the educator here goes beyond merely teaching the student to act ethically, and reaches into the area of the educator's personal engagement with the ethical sphere. The educator should be willing to, firstly, concede that ethics play an important role in people's personal and professional lives and, secondly, become aware of what ethical theories entail through actual study (a critical approach rather than simple statements of their own opinions). Through direct study an educator will have the ability to integrate an ethical approach into individual technical modules of the different courses.

This last point links to the null curriculum, which refers to what is left out of classes (or not taught). This is important because students often interpret that which is not formally taught or stated in classes as unimportant (Flinders et al. 1986). That which we do not teach, thereby giving students the message that these elements are not important in their educational experiences or in our society, is just as important as that which is taught directly (Eisner 1994). By not giving enough attention to ethics in the curriculums of natural science and engineering education, we may unintentionally be giving students the idea that moral considerations are not important in their careers. The integration of ethics beyond the explicit curriculum entails a large amount of additional work which may not be easy to do, however. Some educators may not see the need for increased student education in the fields of ethics and will simply deny that ethical education has any value at all, a view partly motivated by the large amount of additional work that may be needed (for it is a sorry fact of higher education in modern South Africa that many educators are already struggling to cope with ever-increasing numbers of students). Still, it should be recognised that if we do not integrate ethics fundamentally into natural science and engineering courses we are presenting the message to students that this topic is unimportant. I have already mentioned that case studies alone and simple lists of rules to be recalled in certain 'prepared' situations are not enough; the ability to deal with ethical problems should become intrinsic and meta-ethical, a pre-requisite for the scientist's and engineer's way of thinking. Some students already have the capacity to reason in such an intrinsically ethical way, but this does not suggest that it can be assumed that all natural science and engineering students possess this skill. Dynamic topics and diverse students form an intrinsic part of engineering ethics education ( $\mathrm{Li} \& \mathrm{Fu} 2010$ ), a fact that challenges most educators and highlights the need to work hard to meet the needs of different types of students and to prepare them for a wide range of ethical encounters by integrating the hidden and null curriculums with the explicit curriculum.

\section{Addressing worldviews and Christian scholarship}

The null curriculum and hidden curriculum are two target areas that have been identified as the way we as educators teach our students about morality. In essence, a shift in the basic perception of ethics is needed, which requires looking into the way ethical questions are approached. Most natural scientists and engineers are taught to deal with technical problems from a purely positivist perspective, which is an approach suitable for the laboratory or workshop situation. A positivist worldview refers to an approach to reality that is grounded in Positivism, a philosophical system that treats logical and mathematical observations as the only worthwhile source of information for the social and natural sciences, according to Emile Durkheim (Giddens 1976:1-50). But these students are often not taught to deal with the social community which should be served through scientific and technological advancement, as the needs of this broader community often fall beyond the scope of a strictly positivist worldview. This clearly hints at a problematic relationship between a Modern Western worldview (with its foundation in a positivist perspective on reality) and ethics as an important factor in the development of scientists and engineers.

Van der Walt (2008), who considers worldviews from a Reformed Christian perspective, likens the idea of worldview to the words of Matthew 6:22: 'The eye is the lamp of the body. If your eyes are good, your whole body will be full of light.' Not only does a worldview alter one's perception of the outside world, it also directs one's moral framework (direction). James H. Olthuis states that worldview affects both 'our perceptions of the world and our actions in the world'; it acts both descriptively and normatively (Olthuis 1985). These descriptions allude to the fundamental role that worldview plays in everyday life, especially with regard to moral discourse.

In current engineering and natural science teaching approaches, a strictly positivist worldview is cultivated and the complex nuances of the social world are approached in a reductionist manner. How can an engineer or natural scientist function effectively in the overlap of the social world and the world of their profession, let alone deal morally with ethical dilemmas that arise from this situation, if the logical aspects of their technical work are always their chief consideration because of the worldview in which they were trained? If the inherent assumptions that form a person's perception of not only their personal life, but also their profession, attempt 
to ignore or belittle the importance of ethical issues in the social world, how can a student be expected to act morally? The roots of the problem therefore appear to originate in a reductionist worldview that stresses mainly the biotic or physical-energetic facets of life, and places little importance on social and moral ideals.

The importance of a worldview in all aspects of life cannot be over-emphasised, as it influences every aspect of a person's interaction with other people and the surrounding world (Van der Walt 2003:61-64). A one-sided view of the world, emphasising only one or two facets instead of the big picture, leads to a situation where ethical factors play little or no role in decision-making. It should be noted that the concept of worldview has a fundamental basis in the student's religious ${ }^{6}$ conviction (or lack thereof). The positivist perspective that is characteristic of the Modern Western worldview often lends itself to an irreligious (atheistic or, more moderately, agnostic) perspective, a perspective that is sometimes limited in discerning a sense of 'right' and 'wrong'. This is where secular ethics education in the higher education system is beneficial. Ethical considerations are addressed throughout a scientist's or engineer's life, either by means of the normative structure of a certain religious perspective gained in childhood or by earlier education in ethics at pre-university or pre-college level. These frameworks for ethical thought should never be assumed, however, and it falls to higher education in ethics to help a student to respond to moral situations in the workplace scenario if no such framework has been provided by earlier education or religious conviction.

Does this mean that Christians cannot benefit from secular ethics education fundamentally integrated into the higher education curriculum? Most Christian worldviews lend themselves very clearly to a morally-driven approach in fields such as natural science and engineering. The reasoning goes that God's will is made manifest in God's laws (which are both structural and directional and derived from general revelation and the Bible), and that these laws are then formulated as ways of conduct that are applicable to all aspects of life (Van der Walt 2003:102-106). This normative view applies just as strongly to natural science and engineering as it does to everyday moral dilemmas. The desire may therefore be strong to claim that Christians have no need of secular ethics education, for the will of God provides adequate moral motivation.

I believe that the study of ethics is essential to provide Christian scientists and engineers with the ability to consistently apply the ethical imperatives of their Christian faith and convictions in a workplace in which diverse views on morality (which may not necessarily be based on divine commandments) may be found. Whilst Postmodernism encourages an amalgamation of different worldviews (Lyon 1994:1-4), a fragmented view of the world that is partially Christian and partially based on Positivism cannot lead to

6.I take the term 'religious' to refer to the extent to which a person identifies with belief in a divine pow' subscribes to an idnt to its normative practices (Hogg 2009). This definition is presented with the realisation that 'religious' (Hoge 2009). This definition is presented with the realisation that 'religious' may be taken to mean something completely differen in other contexts, but that such a definition works well to describe the 'irreligious' perspective discussed with reference to the Modern Western worldview. the steadfast application of Christian ethics in life. Without integrating a Christian worldview with some form of fundamental ethics training - either through the null and hidden curriculums or by in-depth investigation and critical analysis of a student's personal worldview - a betrayal of the student's basic Christian religious convictions may very well occur (this may be described as hypocrisy: the student's worldview and actions in the world do not correspond because they have not been provided with a broad ethical framework that allows them to apply their religious convictions in a multicultural environment). This is strongly associated with the idea that factors in the world may either influence a person's religious beliefs, or be shaped by them, to change a person's perception of the world (Van der Walt 2003:65-67; Olthuis 1985). Furthermore, a Christian student may adopt a positivist view of the world to solve problems in the workplace in the workplace and, in the process, might lose his or her Christian convictions, if the student does not have carefully-considered and reasoned convictions for holding a Christian worldview. These convictions can be greatly supported by a broader ethical framework.

For these reasons both Christian and non-Christian educators should embrace the concept of ethics training in the higher education of these fields, as such training will lead both Christian and non-Christian students to a better understanding of dealing with moral complexity (whether in the student's own views or in those held in a multicultural milieu). This process of inquiry into ethics and its association with a student's worldview may help the student build his or her views of the world on a firm foundation.

\section{Conclusion}

From a Reformational perspective, Bob Goudzwaard's idea of a simultaneous realisation of norms provides a helpful suggestion for a way forward. This concept states that economic ideals (such as those mentioned in section 1 ) should be balanced with humanistic technological development, and with ethical ideas such as morality and justice. Each of these aspects can be addressed if businesses, governments, consumers and industries were to cooperate to accomplish these important norms simultaneously (this also implies a mutual accountability). Each of these entities should be concerned with the way in which their actions influence society so that a just, efficient and sustainable world can be built (Goudzwaard 1979). In the scientific and engineering world, a closer look at ethics in the higher education system will contribute greatly to the cultivation of this kind of society and world.

Natural science and engineering education in South Africa has traditionally approached the technical training of students and the ethical development of students as two separate aspects in higher education. I suggest that a new stance be taken, whereby ethics is viewed as an integral part of a student's professional and personal development.

When the fields of science and engineering are viewed from a mere positivist perspective, it may be difficult - even impossible - to view ethics as an important facet of the world. However, by its very nature this view is limiting. 
Such a worldview not only restricts the natural scientist or engineer in his or her work, but also neglects the role that he or she must play in the social environment. The service motif of natural scientific development and engineering is, after all, inherently coupled with applications in the social world (where ethical conduct plays a critical role).

Changes in modern economic environments mean that the challenge for future professionals to act ethically will not simply vanish, and may in fact become more and more pressing. The goal of approaching ethics as an integral part of these students' training is therefore not to overload them with 'unnecessary' extra work, but to enhance their ability to function in a competitive market-driven environment. Integrated ethics training has the short term benefit of helping students to deal with personal dilemmas, but it also has the long terms goals of enriching the workplace and increasing the individual's contribution to society. In this article I have tried to show that the 'obstacle' of ethics training in natural science and engineering education may be addressed by looking at the kind of worldview that we unconsciously imprint onto our students and also by utilising the hidden and null curriculums, rather than simply adding extra ethics modules to overfull technical university or college courses. In the overlap between the technical, the economic, the social and the ethical a fruitful conversation can take place within the higher education institutions of South Africa which may eventually lead to the enrichment of all natural science and engineering students. At the very least, a student with training in the field of ethics has a competitive marketplace advantage over one who lacks such training.

\section{Acknowledgements Competing interests}

I declare that I have no significant competing financial, professional or personal interest that might have influenced the performance of the work described in this article.

\section{References}

Engineering Council of South Africa, 2004, 'Standards and Procedures System: Whole Qualification Standard for Bachelor of Science in Engineering (BSc(Eng)) / Bachelors of Engineering (BEng): NQF Level 7', in PE-61/E-02-PE, Rev-2, 26 July 2004.

Engineers' Council for Professional Development, 1947, Canons of ethics for engineers, Engineers' Council for Professional Development, New York.

Eisner, E.W., 1994, The educational imagination: On design and evaluation of school programs, 3rd edn., Macmillan, New York.

Fleck, L., 1979, Genesis and development of a scientific fact, University of Chicago Press, Chicago.

Flinders, D.J., Noddings, N. \& Thornton, S.J., 1986, 'The null curriculum: Its theoretical basis and practical implication', Curriculum Inquiry 16(1). http://dx.doi. org/10.2307/1179551

Florman, S.C., 1994, The existential pleasures of engineering, St Martin's Griffin, New York.

Giddens, A., 1976, Emile Durkheim: Selected Writings, Cambridge University Press, London.

Gil-Martín, L.M., Hernandez-Montes, E. \& Segura-Naya, A., 2010, 'A new experience: The course of ethics in engineering in the Department of Civil Engineering, University of Granada', Science and Engineering Ethics 16(2), 409-413. http:// dx.doi.org/10.1007/s11948-009-9156-z

Goudzwaard., B., 1979, Capitalism and progress: A diagnosis of Western society, Wedge Publication Foundation, Toronto.

Goudzwaard, B., 1984, Idols of our time, Inter-Varsity Christian Fellowship, Downers Grove, IL.
Haws, D.R., 2004, 'The importance of meta-ethics in engineering education', Science and Engineering Ethics 10(2), 204-210.

Hogg, M.A., Adelman, J.R. \& Blagg, R.D., 2009, 'Religion in the face of uncertainty: An uncertainty-identity theory account of religiousness', Personality and Socia Psychology Review 14(1), 172-183.

International Research Ethics Network for Southern Africa, 2011, IRENSA: International Research Ethics Network for Southern Africa, viewed on 27 October 2011, from http://www.irensa.org/

Karim, Q., Karim, S.S., Frohlich, J.A., Grobler, A.C., Baxter, C., Mansoor, L.E., et al., (CAPRISA 004 Trial Group), 2010, 'Effectiveness and safety of tenofovir gel, an antiretroviral microbicide, for the prevention of HIV infection in women', Science 329(5996), 1168-1174. http://dx.doi.org/10.1126/science.1193748

Kobilnyk, A., 2008, 'US 2008 Science budget slashed', in First Science, 04 January, viewed on 05 May 2011, from http://www.firstscience.com/home/perspectives/ editorials/us-2008-science-budget-slashed_41445.html

Kuhn, T., 1962, The Structure of Scientific Revolutions, University of Chicago Press, Chicago.

Lau, A. S., 2004, 'Teaching engineering ethics to first-year college students', Science and Engineering Ethics 10(2), 359-368. http://dx.doi.org/10.1007/s11948-004$0032-6$

Li, J. \& Fu, S., 2010, 'A systematic approach to engineering ethics education', Science and Engineering Ethics 18(2), 339-349.

Lyon, D., 1994, Postmodernity, Open University Press, Buckingham.

McGraw-Hill, 2008, McGraw-Hill Encyclopedia of Science \& Technology, The McGrawHill Companies, Inc., New York.

Mishra, A., 2011, 'India: Science and research spending to double', in University World News, 08 May, viewed 26 May 2011, from http://www.universityworldnews.com/ article.php?story $=20110507093252461$

Mitcham, C., 1994, Thinking through technology: The path between engineering and philosophy, University of Chicago Press, Chicago and London.

Monsma, S.V., 1986, Responsible technology, Calvin Center for Christian Scholarship, Grand Rapids.

National Research Foundation (South Africa), 2009, 'Annual report 2009', in Nationa Research Foundation annual reports, viewed 12 October 2011, from http://www. nrf.ac.za/financial_annual_reports.php

National Research Foundation (South Africa), 2010, 'Annual report 2009 / 2010', in National Research Foundation annual reports, viewed 12 October 2011, from http://www.nrf.ac.za/financial_annual_reports.php

North-West University, 2011, 'Oorsig oor die werksaamhede van die Skool vir Filosofie', in North-West University - Fakulteit Lettere en Wysbegeerte, viewed 17 October 2011, from http://www.nwu.ac.za/af/p-sphil/index a.html

Nussbaum, B., 2009, 'Are engineers, scientists and mathematicians enemies of innovation?', in Bloomberg Businessweek, 16 June, viewed 14 May 2011, from http://www.businessweek.com/innovate/NussbaumOnDesign/archives/2009/06/ are_engineers_scientists_and_mathematicians_enemies_of_innovation.html

Prinsloo, L., 2011, 'SA sets aside R4,4 bn to boost R\&D', in Engineering News, viewed 26 May 2011, from http://www.engineeringnews.co.za/article/science-andtechnology-funding-should-be-improved-pandor-2011-05-24

Olthuis, J.H., 1985, 'On Worldviews', Christian Scholar's Review 14, 153-164.

Rollin, B.E., 2006, Science and Ethics, Cambridge University Press, Cape Town. http:// dx.doi.org/10.1017/СBO9780511617218

Scott, C., 2007, 'South Africa announces "visionary" science budget', in SciDev.Net 22 February, viewed 26 May 2011, from http://web.scidev.net/En/science-andinnovation-policy/university-systems/news/south-africa-announces-visionaryscience-budget.html

Schuurman, E., 1995, 'n Kritiese besinning oor die moderne tegnologie, Potchefstroom Universiteit vir Christelike Hoër Onderwys, Potchefstroom.

Schuurman, E., 2009, Technology and the future: A philosophical challenge, Paideia Books, Grand Rapids.

Semeniuk, I., Tollefson, J. \& Wadman, M., 2011, 'U.S. science agencies targeted for budget cuts', in Scientific American - Nature, 10 February, viewed 05 May 2011, from http:// www.scientificamerican.com/article.cfm?id=us-science-agencies-targeted-f

Shapin, S., 2008, The scientific life: A moral history of a late modern vocation - On the historical development of the character of scientists and the predecessors, Chicago University Press, Chicago.

The South African Research Ethics Training Initiative, 2011, 'Welcome to SARETI: The South African Research Ethics Training Initiative', University of Pretoria SARETI website, viewed 27 October 2011, from http://web.up.ac.za/default. asp?ipkCategoryID $=4264$

U.S. Department of Labor, 2010-2011, 'Occupational Outlook Handbook, 2010-2011 Edition: Engineers', in Bureau of Labor Statistics, viewed 01 May 2011 from http:// www.bls.gov/oco/ocos027.htm

Van der Walt, B.J., 2003, Understanding and rebuilding Africa, ICCA, Potchefstroom.

Van der Walt, B. J., 2008, The eye is the lamp of the body: Worldviews and their impact, The Institute for Contemporary Christianity in Africa, Potchefstroom.

Wilson, E., 1999, Consilience: The unity of knowledge, Vintage, New York.

Yusa, K., Rashid, T., Strick-Marchand, H., Varela, I., Liu, P., Paschon, D.E., et al., 2011, 'Targeted gene correction of $\alpha 1$-antitrypsin deficiency in induced pluripotent stem cells', Nature 478, 391-394. http://dx.doi.org/10.1038/nature10424 